\title{
Analisis Dampak Pembangunan Infrastruktur Terhadap Pertumbuhan Ekonomi Inklusif Provinsi Sumatera Utara
}

\author{
Hendra Andy Mulia Panjaitan*, Sri Mulatsih , Wiwiek Rindayati \\ Departemen Ilmu Ekonomi,Fakultas Ekonomi dan Manajemen, Institut Pertanian Bogor \\ Jalan Agatis, Kampus Darmaga, Bogor 16680, Indonesia \\ *Korespondensi: hendra.panjaitan@gmail.com
}

[diterima: Febuari 2019- revisi: Maret 2019-diterbitkan daring: Juli 2019]

\begin{abstract}
ABSTRAK
Pembangunan infrastruktur merupakan aspek penting dalam peningkatan pertumbuhan ekonomi karena dapat menciptakan lapangan kerja baru, penurunan tingkat kemiskinan dan peningkatan pendapatan perkapita. Pertumbuhan inklusif merupakan bagian dari pertumbuhan ekonomi berkelanjutan sebagaimana tercantum dalam kesepakatan global mengenai Sustainable Development Goals (SDGs), yaitu pertumbuhan ekonomi yang dapat menciptakan pemerataan, menurunkan kemiskinan dan pengangguran, serta mendorong pertumbuhan ekonomi yang lebih cepat. Penelitian ini melakukan analisis mengenai dampak pembangunan infrastruktur terhadap pertumbuhan ekonomi inklusif di Provinsi Sumatera Utara. Estimasi parameter yang digunakan adalah two-stages least square (2SLS). Data yang digunakan adalah 33 kabupaten/kota di Provinsi Sumatera Utara pada periode 2013-2017. Hasil penelitian menunjukkan bahwa pertumbuhan PDRB tidak inklusif, karena dapat meningkatkan GINI di Sumatera Utara.
\end{abstract}

Kata kunci: infrastruktur, pertumbuhan inklusif, simultan, sumatera utara

\begin{abstract}
The development of infrastructures is an important aspect in economic growth. It is because the existence of a infrastructure cause good increasing economic growth, through creation of new jobs, as well as reducing the levels of poverty and increasig per capita income. Inclusive growth is an important part of sustainable economic growth as shown in a global agreement on Sustainable Development Goals (SDGs), where the economic growth that can generate equity, reduce poverty and unemployment, and encourage economic growth faster. Economic growth that can be create equality, reduction poverty and unemployment, as well as the push the growth of economy the more fast. This study conducted an analysis of the impact of infrastructure development on inclusive economic growth in North Sumatra Province. The parameter estimates used are two-stages least square (2SLS). The data used are 33 district / cities in North Sumatra Province in the 2013-2017 period. The results showed that the GRDP growth was not inclusive, because it could increase GINI in North Sumatra.
\end{abstract}

Keywords: infrastructure, inclusive growth, simultaneous equations, north sumatera JEL classification: E20,F16,H30,J62,R23 


\section{PENDAHULUAN}

Pembangunan infrastruktur sangat diperlukan di dalam proses pertumbuhan ekonomi karena dapat mendorong terjadinya pertumbuhan ekonomi, sehingga menciptakan lapangan kerja baru, menurunkan tingkat kemiskinan, dan meningkatkan pendapatan perkapita. Infrastruktur berperan sangat penting dalam pertumbuhan ekonomi suatu daerah. Pembangunan infrastruktur yang baik akan menjamin efisiensi, memperlancar pergerakan barang dan jasa, dan meningkatkan nilai tambah perekonomian (Prasetyo dan Firdaus 2009). Ketersediaan infrastruktur merupakan salah satu faktor pendorong produktivitas daerah.

Pembangunan nasional bertujuan mewujudkan pertumbuhan ekonomi yang berkelanjutan dan inklusif. Pertumbuhan ini merupakan yang memenuhi kebutuhan generasi saat ini tanpa mengurangi kemampuan generasi mendatang, terdistribusi di berbagai wilayah, dan dapat mengurangi ketidaksetaraan pendapatan. Pembangunan yang berkelanjutan menjadi syarat perlu bagi keberhasilan suatu negara, namun demikian belum cukup apabila tidak diikuti dengan pembangunan yang inklusif. Pembangunan yang inklusif dimaknai sebagai pertumbuhan yang tidak hanya menciptakan peluang ekonomi baru, tetapi juga menjamin aksesibilitas yang sama terhadap peluang yang tercipta untuk semua segmen masyarakat, khususnya bagi masyarakat miskin (Prasetyo dan Firdaus 2009).

Pertumbuhan inklusif merupakan bagian besar dari pertumbuhan ekonomi berkelanjutan sebagaimana tercantum dalam kesepakatan global mengenai Sustainable Development Goals (SDGs). yaitu pertumbuhan ekonomi yang dapat menciptakan pemerataan, menurunkan kemiskinan dan pengangguran, serta mendorong pertumbuhan ekonomi yang lebih cepat. Empat indikator tersebut dapat didefenisikan pertumbuhan ekonomi yang dapat mereduksi kemiskinan, ketimpangan pendapatan antar individu, dan tingkat pengangguran (Klasen 2010, Ianchovichina, dan Gable 2012).

Rencana Pembangunan Jangka Menengah Daerah (RPJMD) Provinsi Sumatera Utara 20132018 telah menetapkan visi Sumatera Utara
2013-2018, yaitu menjadikan provinsi yang berdaya saing menuju Sumatera Utara Sejahtera. Visi ini bermakna bahwa pemerintah daerah berkomitmen untuk melakukan pembangunan menuju kearah yang lebih baik, melalui pembangunan ekonomi dan pembangunan manusia. Pembangunan ekonomi bertujuan untuk meningkatkan daya saing, sehingga mampu berkompetisi dengan memanfaatkan sumber daya, ilmu pengetahuan dan teknologi secara optimal. Pembangunan manusia bertujuan agar masyarakat memiliki kompetensi yang tinggi, berintegritas dan religius. Berbagai strategi telah ditetapkan sebagai langkah untuk mewujudkan visi dan misi dalam RPJMD Provinsi Sumatera Utara 2013-2018. Terkait dengan kesejahteraan rakyat, pemerintah Provinsi Sumatera Utara menetapkan strategi peningkatan kualitas, kuantitas, dan kapasitas sarana dan prasarana pendidikan, kesehatan, dan penunjang kesejahteraan masyarakat.

Indikator ekonomi makro untuk mengukur pertumbuhan ekonomi suatu negara yaitu Produk Domestik Bruto (PDB). PDB pada tingkat provinsi dan kabupaten/kota disebut Produk Domestik Regional Bruto (PDRB). Indikator untuk mengukur ketimpangan pendapatan yaitu Koefisien Gini (BPS 2017b).

Indikator pertumbuhan inklusif antar wilayah di Provinsi Sumatera Utara menunjukkan adanya ketimpangan antar kabupaten/kota. Berdasarkan Gini Rasio di Sumatera Utara tahun 2017 antar kabupaten kota di Provinsi Sumatera Utara (BPS 2017b), tingkat ketimpangan pendapatan Provinsi Sumatera Utara tahun 2017 dibawah tingkat ketimpangan nasional yaitu 0.32. Kabupaten Labuhan Batu Selatan memiliki Gini Rasio terendah yaitu 0.22 , sedangkan Kota Medan dan Kota Gunung Sitoli Gini Rasio tertinggi yaitu 0.35 .

Pertumbuhan ekonomi di Provinsi Sumatera Utara telah banyak melakukan pembangunan infrastruktur, namun apakah pertumbuhan telah inklusif dan bagaimana efek dari pembangunan infrastruktur di Provinsi Sumatera Utara, serta penelitian ini dilakukan untuk melihat perkembangan dan pengaruh program pembangunan infrastruktur dan bidang ekonomi.

Studi terkait pertumbuhan inklusif yang menguraikan hubungan simultan antara indikator 
capaian pertumbuhan inklusif masih terbatas. Sebagian besar penelitian menghitung indeks capaian pertumbuhan inklusif yang konsep penghitungannya sangat beragam dan memiliki hasil yang beraneka ragam. Oleh karena itu, penelitian ini mencoba untuk melihat hubungan indikator pertumbuhan inklusif dengan model persamaan simultan untuk melihat keterkaitan hubungan antar indikator apakah sudah simultan yang merupakan syarat dari inklusifitas.

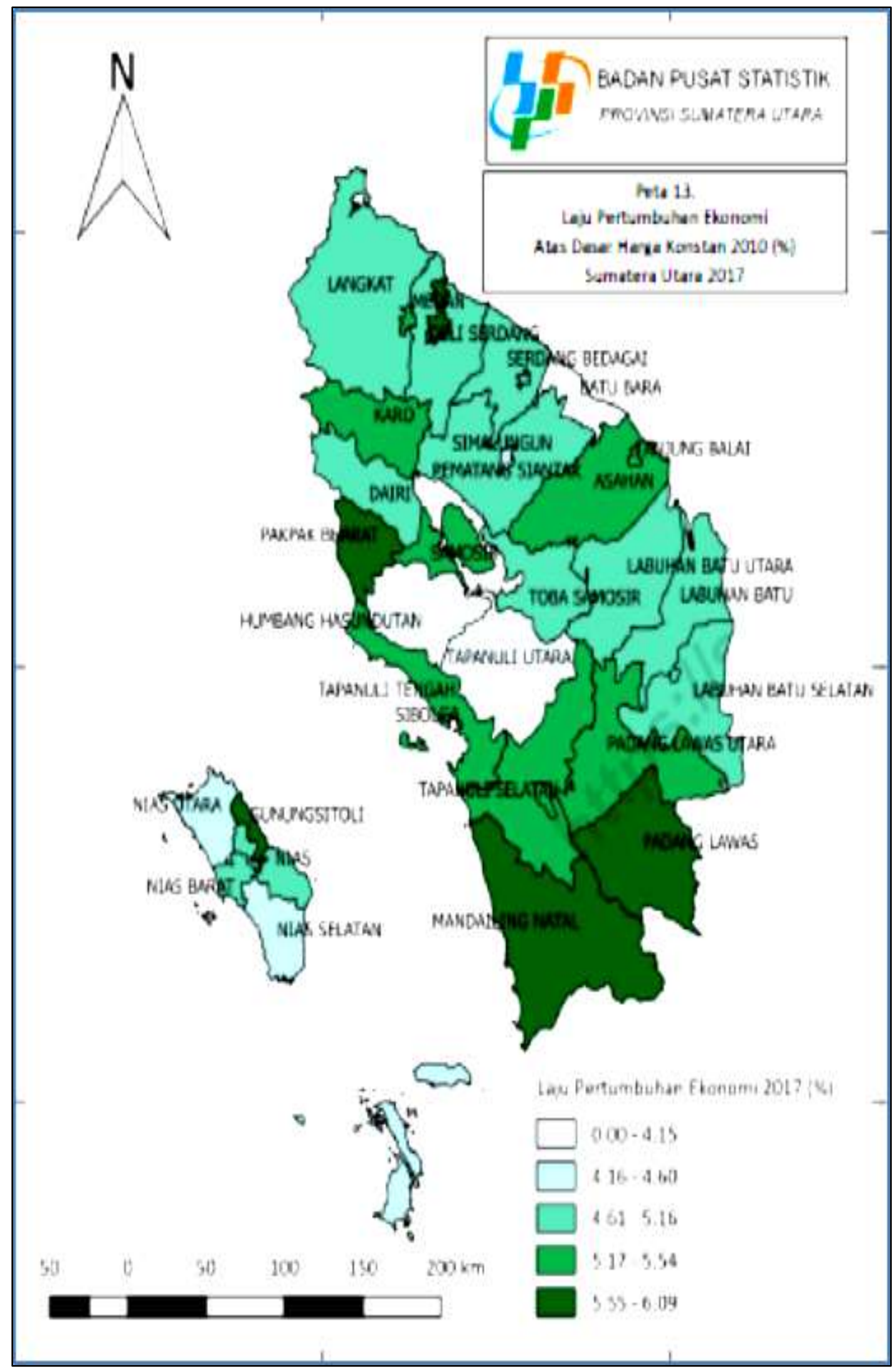




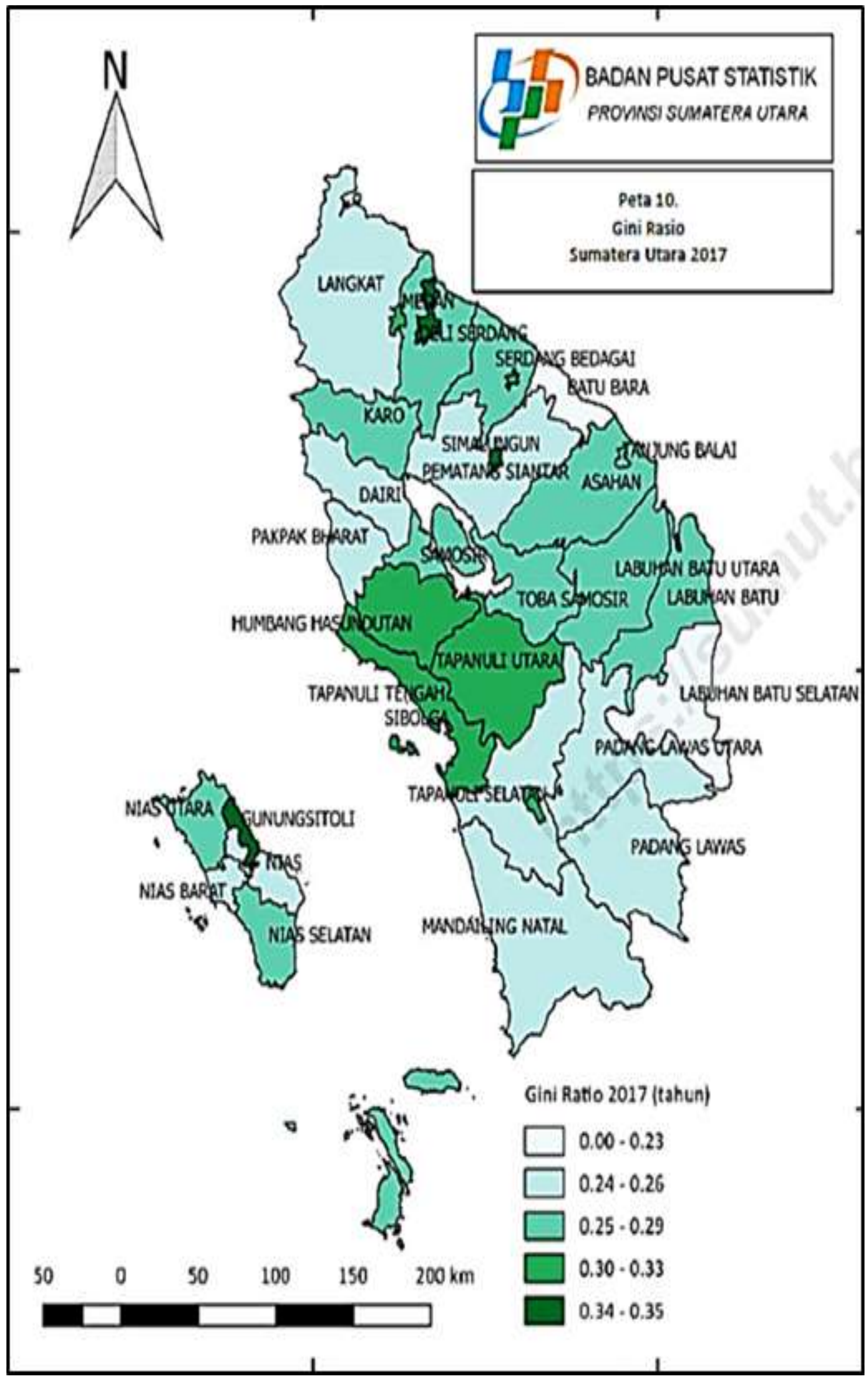

Gambar 1. Peta Tematik Laju Pertumbuhan dan Gini Rasio Provinsi Sumatera Utara 2017 Sumber: Badan Pusat Statistik Tahun 2017 
Berdasarkan uraian di atas, maka tujuan penelitian adalah (1) Memberikan gambaran mengenai capaian pertumbuhan inklusif di Provinsi Sumatera Utara, (2) Menganalisis inklusifitas pertumbuhan ekonomi Sumatera Utara melalui pola hubungan indikator pertumbuhan inklusif, (3) Mengukur dampak pembangunan infrastruktur terhadap pertumbuhan inklusif di Provinsi Sumatera Utara.

Indikator pertumbuhan inklusif antar wilayah di Provinsi Sumatera Utara menunjukkan adanya ketimpangan antar kabupaten/kota. Salah satu indikator utama pertumbuhan inklusif adalah tingkat ketimpangan. Gambar 1 menunjukkan adanya ketimpangan capaian Gini Rasio di Sumatera Utara tahun 2017 antar kabupaten/kota di Provinsi Sumatera Utara .Tingkat ketimpangan pendapatan Sumatera Utara tahun 2017 selalu dibawa tingkat ketimpangan nasional yaitu 0.32. Kabupaten Labuhanbatu selatan tercatat gini rasio terendah yaitu 0.22 sedang Kota Medan dan Kota Gunung Sitoli tercatat gini rasio tertinggi yaitu 0.35. Indikator ekonomi makro untuk mengukur pertumbuhan ekonomi suatu negara yaitu Produk Domestik Bruto (PDB). PDB pada tingkat provinsi dan kabupaten/kota disebut Produk Domestik Regional Bruto (PDRB).

Keadaan perekonomian Sumatera Utara terus mengalami peningkatan. Hal ini tercermin dari indikator pertumbuhan ekonomi yang senantiasa positif, dimana Produk Domestik Regional Bruto (PDRB) mengalami kenaikan sejak tahun 2010 senilai 331.08 triliun rupiah menjadi 463.78 triliun rupiah di tahun 2016. Pencapaian pertumbuhan tersebut hendaknya menciptakan peluang ekonomi yang dapat diakses oleh seluruh lapisan masyarakat, yang disebut sebagai pertumbuhan ekonomi inklusif (Inklusif Growth), berdasarkan data penduduk tahun 2010 penduduk Sumatera Utara 130287 jiwa dengan 11.36 persen penduduk miskin namun pada tahun 2016 penduduk Sumatera Utara tercatat kurang lebih 141 ribu jiwa dengan 10.35 persen penduduk miskin. Pertumbuhan inklusif memungkinkan seluruh individu ikut berkontribusi dan mendapatkan manfaat dari laju pertumbuhan ekonomi.

Masalah ketenagakerjaan Provinsi Sumatera Utara diperkirakan akan semakin kompleks.
Indikasi ini terlihat di samping pertambahan penduduk usia kerja setiap tahunnya yang terus meningkat sebagai implikasi dari jumlah penduduk yang cukup besar. Selain itu struktur umur yang cenderung mengelompok pada usia muda juga masih tingginya angka pengangguran terutama pengangguran terbuka. Oleh sebab itu pembangunan ketenagakerjaan dititikberatkan pada tiga masalah pokok, yakni perluasan dan pengembangan lapangan kerja, peningkatan kualitas dan kemampuan tenaga kerja serta perlindungan tenaga kerja.

Gambaran mengenai ketenagakerjaan di Provinsi Sumatera Utara dalam bagian ini akan disajikan kondisi ketenagakerjaan dilihat dari penduduk usia kerja, dan Tingkat Partisipasi Angkatan kerja (TPAK), dan Tingkat Penganggguran Terbuka (TPT). Selain itu, disajikan pula secara singkat indikator-indikator ketenagakerjaan yang meliputi, status pekerjaan, lapangan pekerjaan, jenis pekerjaan, serta jam kerja. Secara umum, selama tahun 2015 sampai 2017 terjadi peningkatan kondisi ketenagakerjaan di Sumatera Utara. Tahun 2017 jumlah penduduk usia kerja di Sumatera Utara adalah 9.79 juta jiwa yang terdiri dari 6.74 juta angkatan kerja dan sisanya sebanyak 3.05 juta bukan angkatan kerja. Selanjutnya TPAK, merupakan indikator yang mampu menggambarkan sejauh mana peran angkatan kerja di suatu daerah. Semakin tinggi nilai TPAK semakin besar pula keterlibatan penduduk usia kerja dalam pasar kerja.

TPAK Sumatera Utara tahun 2017 adalah sebesar 68.88 persen, artinya bahwa pada tahun 2017 sebanyak 68.88 persen penduduk usia kerja di Sumatera Utara siap terjun dalam pasar kerja baik itu bekerja atau mencari kerja/ mempersiapkan usaha. Jika dilihat perkembangannya, tingkat partisipasi angkatan kerja di Sumatera Utara menunjukkan kecenderungan turun naik. Pada tahun 2015, TPAK Sumatera Utara 67.28 persen, kemudian turun menjadi 65.99 persen pada tahun 2016 dan pada tahun 2017 kembali naik menjadi 68.88 persen. Hal ini disebabkan penduduk usia kerja yang sebelumnya mengurus rumah tangga atau lainnya beralih menjadi bekerja atau sebaliknya, dikarenakan berbagai macam alasan. 


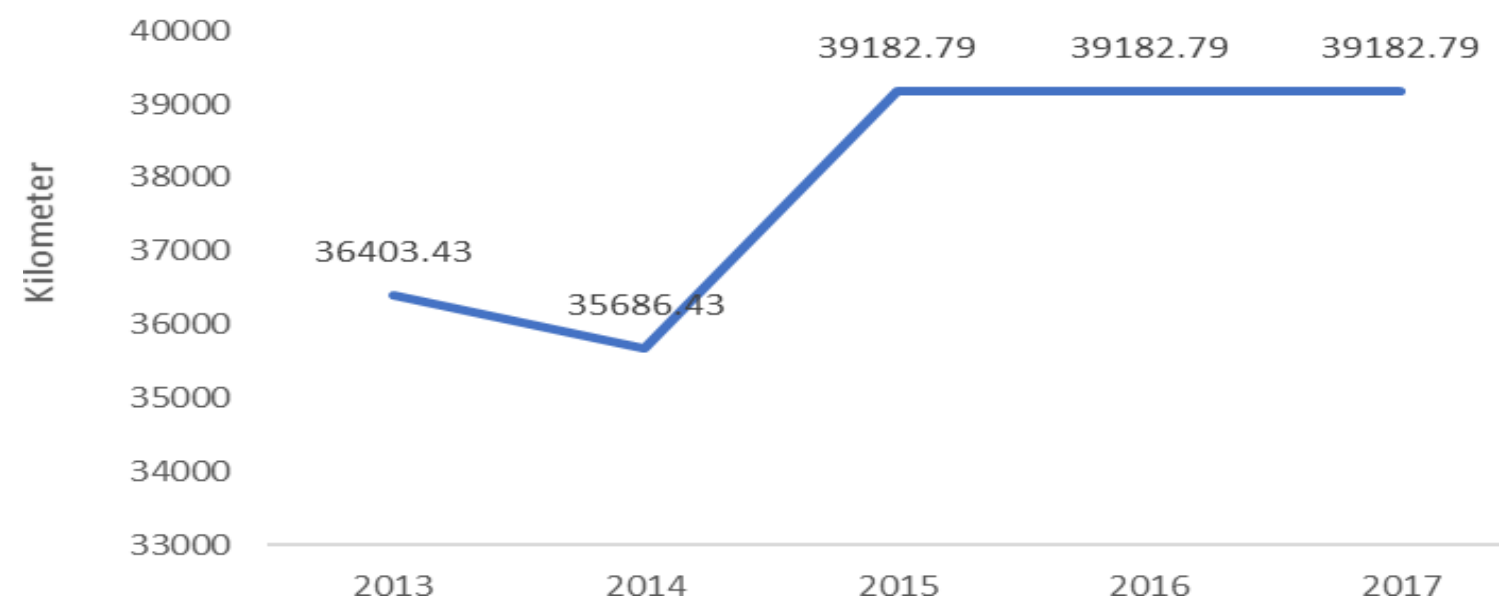

Gambar 2. Perkembangan Panjang Jalan di Sumatera Utara Tahun 2013-2017

Sumber : Badan Pusat Statistik Tahun 2013-2017

Ketersediaan infrastruktur merupakan salah satu faktor pendorong produktivitas daerah. Pemerintah akan memprioritaskan pengalokasian nya anggaran infrastruktur dalam APBN dan APBD dengan harapan cara tersebut pengangguran dapat teratasi dan dikurangi, serta infrastruktur perekonomian yang diperlukan untuk menggerakkan sektor riil bisa ditingkatkan lebih baik lagi sehingga angka kemiskinan serta ketimpangan sosial dapat dikurangi. Upaya pemerintah pusat dan daerah melindungi dan membantu meringankan beban golongan menengah kebawah yang mengalami kesulitan di bidang perekonomian (Prasetyo dan Firdaus 2009).

Pembangunan infrastruktur di Provinsi Sumatera Utara sudah dilakukan pemerintah pusat dan pemerintah daerah. Pembangunan infrastruktur jalan raya seperti jalan kabupaten dan jalan provinsi sudah hampir mencapai seluruh daerah kabupaten/kota di Provinsi Sumatera Utara. Panjang jalan di Sumatera Utara mengalami peningkatan secara dramatis yaitu pada tahun 2014 sekitar 35 ribu kilometer menjadi sekitar 39 ribu kilometer tahun 2015, hal ini di sebabkan meningkatnya pembangunan infrastruktur jalan di kabupaten/kota akibat adanya program Dana Alokasi Khusus dan program infrastruktur pemerintah pusat yang melakukan pembangunan infrastruktur jalan di kabupaten/kota di Provinsi Sumatera Utara.
Kebutuhan tenaga listrik di Sumatera Utara dipenuhi oleh Perusahaan Listrik Negara (PLN), dan sebagian lainnya dipenuhi oleh listrik non PLN. Selama periode tahun 2009-2017 terjadi penambahan pembangkit listrik PLN untuk wilayah Sumatera Utara, dimana pada tahun 2009 daya yang terpasang sebesar 1754.28 MW meningkat menjadi $3083 \mathrm{MW}$ pada tahun 2017. Jumlah listrik yang diproduksi (dibangkitkan sendiri dan dibeli) oleh PLN Sumbagut pada tahun 2017 sebesar 12886.86 GWH. Kemudian energi listrik tersebut didistribusikan oleh PLN Sumbagut ke PLN Wilayah Sumatera Utara sebesar 11744.69 GWH. Pada tahun 2017 jumlah energi listrik yang dijual PLN Wilayah Sumut kepada konsumen di Sumatera Utara sebanyak 3477.477 pelanggan adalah sebesar 9 707.33 GWH (BPS 2017h).

Air bersih yang disalurkan PDAM Sumatera Utara selama tahun 2017 mengalami peningkatan bila dibandingkan pada tahun sebelumnya. Air yang disalurkan kepada konsumen tahun 2016 sebanyak 240.841 juta $\mathrm{m}^{3}$ naik menjadi 245.824 juta $\mathrm{m}^{3}$ pada tahun 2017. Jumlah air bersih yang disalurkan PDAM kepada konsumen terbesar adalah di Kota Medan yakni sebesar 153.249 juta $\mathrm{m}^{3}$ atau sebesar 62.34 persen dari total air yang disalurkan di Sumatera Utara (BPS 2017h). 


\section{TINJAUAN PUSTAKA}

Klasen (2010) mendefinisikan pertumbuhan inklusif sebagai pertumbuhan yang mampu menurunkan disparitas antar kelompok pendapatan. Berdasarkan penelitian sebelumnya dapat ditarik kesimpulan bahwa pertumbuhan ekonomi dapat dikatakan inklusif apabila pertumbuhan tersebut dapat menurunkan tingkat kemiskinan, ketimpangan distribusi pendapatan, dan pengangguran.

Wie (1983) berpendapat bahwa negara yang semata-mata hanya menekankan pada pertumbuhan ekonomi, tanpa memikirkan pendistribusian pendapatan tersebut akan memunculkan ketimpangan. Konsep ketimpangan yang digunakan dalam penelitian ini adalah ketimpangan pendapatan antar golongan atau ketimpangan relatif, ketimpangan pendapatan antar golongan ini biasanya di ukur dengan menggunakan koefisien gini. Kendati koefisien gini bukan merupakan indikator yang ideal mengenai ketimpangan pendapatan antar berbagai golongan, namun sedikitnya angka ini dapat memberikan gambaran mengenai kecenderungan umum dalam pola distribusi pendapatan.

Menurut World Bank (1994), infrastruktur adalah satu set struktur yang bergabung satu dengan yang lain dan membentuk satu rangka yang menyokong keseluruhan struktur tertentu. Misalnya, infrastruktur pengangkutan yang mencakup di dalamnya berupa rel kereta api, jalan raya, lapangan terbang, pelabuhan serta elemen-elemen lain yang masih bersangkutan dengan pengangkutan atau transportasi.

Infrastruktur dibagi menjadi menjadi tiga oleh The World Bank (1994) yaitu (1) Infrastruktur ekonomi, merupakan infrastruktur fisik yang diperlukan dalam menunjang aktivitas ekonomi, meliputi publicutilities (tenaga, telekomunikasi, air, sanitasi, gas), public work (jalan, bendungan, kanal, irigasi dan drainase) dan sektor transportasi (jalan, rel, pelabuhan, lapangan terbang dan sebagainya) (2) Infrastruktur sosial, meliputi pendidikan, kesehatan, perumahan dan rekreasi (3) Infrastruktur administrasi, meliputi penegakan hukum, control administrasi dan koordinasi.
Definisi infrastruktur yang merujuk pada sistem fisik dalam menyediakan transportasi, pengairan, drainase, bangunan-bangunan gedung dan fasilitas publik lain seperti listrik, telekomunikasi, air bersih dan sebagainya, yang dibutuhkan untuk memenuhi kebutuhan dasar manusia dalam lingkup sosial dan ekonomi. Dalam kehidupan masyarakat sistem infrastruktur sebagai pendukung utama fungsi-fungsi sistem sosial dan sistem ekonomi. Definisi sistem infrastruktur sebagai fasilitas-fasilitas atau struktur-struktur dasar, peralatan-peralatan, instalasi-instalasi yang dibangun dan dibutuhkan untuk berfungsinya sistem sosial dan sistem ekonomi masyarakat (Grigg 1988 dalam Fadel Muhammad 2004).

Sementara itu, Brenneman dan Kerf (2002) dalam penelitiannya mengenai "Infrastructure and Poverty Linkages: A Literature Review" menemukan bahwa infrastruktur dibidang transportasi, telekomunikasi, dan energi; memberikan dampak yang sangat kuat terhadap peningkatan pertumbuhan. Sementara itu, pembangunan infrastruktur air dan sanitasi belum memberikan dampak yang signifikan.

Gagasan mengenai pertumbuhan inklusif diawali dengan adanya konsep pertumbuhan propoor. Kakwani dan Pernia (2000) menyoroti bagaimana pertumbuhan ekonomi dapat dikatakan sebagai pro-poor dengan mendefinisikan pertumbuhan pro-poor sebagai pertumbuhan yang didalamnya terdapat partisipasi aktif dan memberikan keuntungan secara signifikan bagi penduduk miskin.

Dornbusch et al. (2004) menyatakan bahwa pertumbuhan ekonomi adalah tingkat kenaikan dari Produk Domestik Bruto (PDB), yang pada tingkat regional disebut Produk Domestik Regional Bruto (PDRB). PDB atau DRB adalah nilai dari seluruh barang dan jasa yang diproduksi pada suatu wilayah dengan jangka waktu tertentu. Produksi tersebut dikonversi dalam bentuk mata uang negara yang bersangkutan agar dapat diagregasikan. Pertumbuhan ekonomi dapat diukur dari perubahan peningkatan PDRB riil pada periode tertentu. Perubahan PDRB riil dari waktu ke waktu mencerminkan perubahan kuantitas dan sudah tidak mengandung unsur perubahan harga, baik inflasi maupun deflasi. 
Capello (2007) menyatakan hubungan antara infrastruktur dan pertumbuhan ekonomi dimana infrastruktur merupakan faktor dalam penentuan daya saing dan produktivitas. Infrastruktur ekonomi akan berdampak langsung terhadap pertumbuhan ekonomi dan pembangunan regional, sedangkan infrastruktur sosial berdampak langsung pada kualitas hidup dan modal manusia, sehingga akan berpengaruh pada produksi hanya dalam jangka panjang dan efeknya tidak hanya berdampak pada area yang dibangun infrastruktur sosial tersebut.

Penelitian Gibson dan Olivia (2009) membuktikan bahwa kualitas dari infrastruktur jalan dan listrik memengaruhi lapangan kerja dan pendapatan dari usaha nonpertanian masyarakat perdesaan di Indonesia. Kurangnya akses terhadap infrastruktur jalan dan listrik serta rendahnya kualitas infrastruktur menghambat usaha nonpertanian rumah tangga perdesaan. Rumah tangga cenderung tidak memiliki usaha nonpertanian dan berpendapatan di bawah usaha nonpertanian apabila mereka tinggal di daerah yang lebih terpencil, memiliki kualitas jalan yang buruk, tidak ada akses listrik, dan sering menderita pemadaman listrik.

Pertumbuhan ekonomi dapat diartikan sebagai perbandingan PDB suatu wilayah periode aktual terhadap PDB periode sebelumnya. Sukirno (2012) mendefinisikan pertumbuhan ekonomi sebagai perkembangan kegiatan dalam perekonomian yang menyebabkan barang dan jasa yang diproduksi dalam masyarakat bertambah, yang merupakan output perekonomian yang terdiri dari barang dan jasa (Mankiw 2016).

Crescenzi dan Pose (2012) menyatakan infrastruktur memainkan peran yang penting dalam pembangunan. Dalam teori-teori pertumbuhan, infrastruktur secara khusus masuk dalam modal publik dan sering disebut sebagai faktor produksi tidak dibayar yang mendorong secara langsung peningkatan produksi. Di lain sisi infrastruktur juga sering disebut sebagai faktor penambah dimana akan mendorong terjadinya peningkatan produktivitas.

Infrastruktur juga sebagai faktor pemicu yang berkontribusi untuk meningkatkan kesejahteraan individu. Kemiskinan dapat diartikan sebagai kondisi relatif dan kondisi absolut. Seseorang dikatakan miskin relatif jika pendapatan dan akses terhadap barang dan jasa relatif rendah dibandingkan rata-rata orang lain dalam suatu perekonomian. Sedangkan seseorang dikatakan miskin absolut apabila tidak mampu memenuhi kebutuhan dasar yang telah ditetapkan secara terstandar sebagai syarat hidup layak (Todaro 2000). Kemiskinan secara umum dapat diartikan sebagai ketidakmampuan seseorang untuk memenuhi kebutuhan dasar standar atas setiap aspek kehidupannya.

Badan Pusat Statistik mendefinisikan pengangguran sebagai angkatan kerja (i) yang tidak bekerja dan sedang mencari pekerjaan; (ii) yang tidak bekerja dan mempersiapkan usaha; (iii) yang tidak bekerja dan tidak mencari pekerjaan karena merasa tidak mungkin mendapatkan pekerjaan; serta, (iv) yang sudah diterima bekerja tetapi belum mulai bekerja. Pengangguran dapat disebabkan perubahan kondisi perekonomian berupa penurunan produksi perusahaan pada tingkat mikro dan penurunan permintaan agregat pada tingkat makro maupun ketidakmampuan industri dan perusahaan dalam menyesuaikan struktur kegiatan ekonomi berupa adanya barang substitusi, perubahan teknologi, meningkatnya biaya produksi sehingga memaksa perusahaan untuk memangkas jumlah pekerja.

Capaian dimensi pertumbuhan inklusif tersebut dipengaruhi oleh pembangunan infrastruktur. Michael dalam ADB (2012), misalnya menemukan bahwa Infrastruktur dapat menciptakan lapangan kerja dan aktivitas ekonomi. Pengeluaran untuk infrastruktur dapat menstimulasi aktivitas ekonomi, meningkatkan kesempatan ekonomi, dan pada akhirnya menciptakan lapangan kerja. Calderon dan Serven (2005) juga membuktikan bahwa infrastruktur memiliki dampak yang signifikan positif pada pertumbuhan ekonomi dan signifikan negatif pada ketimpangan.

\section{METODE}

\section{Kerangka Pikir Keterkaitan Infrastruktur dan Pertumbuhan Inklusif}

Perekonomian Sumatera Utara terus mengalami peningkatan. berdasarkan indikator pertumbuhan ekonomi yang senantiasa positif, dimana Produk Domestik Regional Bruto 
(PDRB) mengalami kenaikan sejak tahun 2010 senilai sekitar 331 triliun rupiah menjadi sekitar 463 triliun rupiah di tahun 2016. Pencapaian pertumbuhan tersebut hendaknya menciptakan peluang ekonomi yang dapat diakses oleh seluruh lapisan masyarakat, yang disebut sebagai pertumbuhan ekonomi inklusif (Inklusif Growth), yaitu dapat mengurangi kesenjangan antara golongan kaya dan golongan miskin.

Infrastruktur berperan penting dalam meningkatkan pertumbuhan ekonomi di mana pertumbuhan ekonomi yang lebih tinggi dijumpai pada wilayah dengan tingkat ketersediaan infrastruktur yang mencukupi World Bank (1994). Pembangunan infrastruktur sangat berpengaruh terhadap pertumbuhan inklusif. Penelitian ini akan melihat dampak pembangunan infrastruktur ekonomi yaitu pembangunan infrastruktur jalan, ketersedian fasilitas air ledeng bagi rumah tangga dan ketersedian fasilitas listrik bagi rumah tangga yang ada di wilayah kabupaten/kota di Provinsi Sumatera Utara. Hasil yang ingin dicapai dari pembangunan infrastruktur adalah menciptakan lapangan kerja dan meningkatkan pertumbuhan ekonomi daerah dengan adanya aktivitas ekonomi yang dapat meningkatkan kesejahteraan masyarakat sehingga dapat menurunkan angka kemiskinan kabupaten/ kota di Provinsi Sumatera Utara.

Infrastruktur dapat menciptakan lapangan kerja dan aktivitas ekonomi. Pengeluaran untuk infrastruktur dapat menstimulasi aktivitas ekonomi, meningkatkan kesempatan ekonomi, dan pada akhirnya menciptakan lapangan kerja. Calderon dan Serven (2005) juga membuktikan bahwa infrastruktur memiliki dampak yang signifikan positif pada pertumbuhan ekonomi dan signifikan negatif pada ketimpangan. Penelitian Gibson dan Olivia (2009) membuktikan bahwa kualitas dari infrastruktur jalan dan listrik memengaruhi lapangan kerja dan pendapatan dari usaha nonpertanian masyarakat perdesaan di Indonesia.

Isu pertumbuhan inklusif (inclusive growth) mulai diperkenalkan oleh Kakwani dan Pernia (2000) dan dikembangkan oleh Ali dan Son (2007) dan Klasen (2010). Penelitian tentang pertumbuhan inklusif oleh Klasen (2010), Rusasta (2011), Ianchovichina dan Gable (2012) dapat dirumuskan bahwa pertumbuhan inklusif merupakan pertumbuhan ekonomi yang dapat mereduksi kemiskinan, ketimpangan pendapatan antar individu, dan tingkat pengangguran.

\section{Jenis dan Sumber Data}

Penelitian ini menggunakan data sekunder dari Badan Pusat Statistik (BPS) Data yang digunakan untuk analisis mencakup 33 kabupaten dan kota di provinsi Sumatera Utara dengan periode 2013-2017. Pengolahan data dilakukan dengan menggunakan program Eviews 9.0.

Data yang digunakan untuk kajian ini adalah data panel. Data panel lebih mampu menggambarkan fenomena yang bersifat dinamis dibandingkan dengan data timeseries atau data cross-section (Baltagi 2005). Penggunaan data time series dengan satu angka tunggal saja untuk mewakili seluruh provinsi akan menghilangkan keragaman dari karakteristik yang ada di masingmasing provinsi tersebut. Penggunaan data crosssectional dengan periode penelitian satu tahun saja tidak dapat menggambarkan perubahan kondisi infrastruktur dan dimensi pertumbuhan inklusif yang digunakan.

\section{Metode Analisis dan Pengolahan Data}

Metode yang digunakan untuk menganalisis data dalam penelitian ini yaitu metode analisis deskriptif dan metode analisis kuantitatif. Metode analisis deskriptif digunakan untuk menerangkan gambaran umum perkembangan variabel pertumbuhan ekonomi, Gini Ratio, dan variabelvariabel lainnya untuk di provinsi Sumatera Utara. Metode analisis kuantitatif yang digunakan dalam penelitian ini yaitu analisis regresi data panel dengan model persamaan simultan (simultaneous equations model).

Analisis model persamaan simultan dalam kajian ini dilakukan dengan proses statistik yang cukup kompleks dengan mempertimbangkan tahapan yang dikemukakan oleh Gujarati dan Porter (2009) serta Rhoads (1991). Tahapan tersebut adalah sebagai berikut:

1. Penentuan variabel endogen dan variabel eksogen yang digunakan dalam setiap persamaan struktural.

2. Pengujian simultanitas dari variabel endogen.

3. Identifikasi model persamaan struktural dengan order condition dan rank condition. 
4. Estimasi persamaan reduced form.

5. Estimasi persamaan struktural menggunakan metode least square (ILS) atau metode twostage least square (2SLS) berdasarkan hasil identifikasi model persamaan.

6. Pengujian asumsi klasik persamaan struktural.

7. Interpretasi model yang digunakan dan penarikan kesimpulan.

\section{Analisis Data Panel}

Data yang dipergunakan dalam analisis ekonometrika terdiri dari tiga jenis, yaitu data time series, data cross section dan data panel. Pada data time series, beberapa variabel akan diobservasi dalam kurun waktu tertentu sedangkan untuk data cross section, beberapa variabel dikumpulkan dari beberapa unit sampel dalam titik waktu tertentu. Pada data panel merupakan gabungan antara data time series dan data cross section, dimana unit cross section yang sama diukur pada waktu yang berbeda. Maka dengan kata lain, data panel merupakan data dari beberapa individu sama yang diamati dalam kurun waktu tertentu. Jika kita memiliki $\mathrm{T}$ periode waktu $(\mathrm{t}=1,2, \ldots, \mathrm{T})$ dan $\mathrm{N}$ jumlah individu $(\mathrm{i}=1,2, \ldots, \mathrm{N})$, maka dengan data panel kita akan memiliki total unit observasi sebanyak $\mathrm{N} x$ T. Jika jumlah unit waktu sama untuk setiap individu, maka data disebut balanced panel. Jika sebaliknya, yakni jumlah unit waktu berbeda untuk setiap individu, maka disebut unbalanced panel.

Regresi dengan menggunakan data panel disebut dengan model regresi data panel. Seperti pada analisis regresi berganda, regresi data panel digunakan untuk melihat pengaruh beberapa variabel bebas terhadap variabel tidak bebas. Namun, ada perbedaan yang mendasar antara regresi data panel dengan regresi klasik. Di dalam model regresi klasik, gangguan (error terms/disturbance) selalu dinyatakan bersifat homoskedastik dan serial uncorrelated. Implikasinya, penggunaan metode Ordinary Least Square (OLS) akan menghasilkan penduga yang bersifat Best Linier Unbiased Estimator (BLUE). Asumsi tersebut tidak dapat diterapkan kepada metode data panel yang disusun berdasarkan atas beberapa individu untuk beberapa periode. Hal ini dikarenakan bertambahnya gangguan yang kini menjadi 3 macam yaitu: gangguan antar waktu (time series disturbance), antar individu (disturbance), dan gangguan antar waktu dan antar individu (time series and cross section disturbance).

Penelitian ini menggunakan model persamaan simultan dengan metode two-stage least square (2SLS). Data dikumpulkan dari 33 kabupaten/ kota di Provinsi Sumatera Utara (2013-2017). Model persamaan simultan digunakan untuk melihat hubungan yang saling memengaruhi antar variabel ekonomi yang terangkum dalam satu sistem persamaan simultan.

Model persamaan simultan yang terbentuk terdiri dari empat persamaan struktural, yaitu:

$$
\begin{aligned}
\text { PDRB }_{i t}= & \alpha_{1}+\beta_{11} \text { GINI }_{i t}+\beta_{12} \ln D A K_{i t} \\
& +\beta_{13} \ln P M T B_{i t}+u_{1, i t} \\
\text { Bekerja }_{i t}= & \alpha_{2}+\beta_{21} \operatorname{lnPDRB}_{i t} \\
& +\beta_{22} \operatorname{lnJALAN}_{i t} \\
& +\beta_{23}{\text { Listrik_ } P_{i t}+u_{2 . i t}} \\
\text { Miskin }_{i t}= & \alpha_{3}+\beta_{31} \operatorname{lnPDRB_{it}}+\beta_{32} \text { Air }_{-} P_{i t} \\
& +u_{2 . i t} \\
\text { Gini }_{i t}= & \alpha_{4}+\beta_{41} \operatorname{lnPDRB}_{i t} \\
& +\beta_{42} \operatorname{lnJ} \ln \ln N_{i t}+\beta_{43} \ln D B H P_{i t} \\
& +u_{3 . i t}
\end{aligned}
$$

Keterangan :

lnPDRB : logaritma natural dari PDRB provinsi (tahun dasar 2010).

BEKERJA : persentase penduduk bekerja dari keseluruhan penduduk usia kerja (persen).

MISKIN : persentase penduduk miskin kabupaten/kota (persen).

GINI : persentase gini kabupaten/kota (persen).

lnDAK : dana alokasi khusus di setiap kabupaten/kota (rupiah).

lnPMTB : pertambahan modal tetap bruto di setiap kabupaten/kota (rupiah).

lnJALAN : jumlah panjang jalan $(\mathrm{km})$ di setiap kabupaten/kota. 

LISTRIK_P : persentase rumah tangga yang
lnDBHP : dana bagi hasil pajak yang di mengakses listrik di setiap peroleh dari pemerintah pusat di kabupaten/kota (persen). setiap kabupaten/kota (rupiah).
AIR_P : persentase rumah tangga yang mengakses air ledeng di setiap
u_1it,..,u_4it : error term masing-masing kabupaten/kota (persen). persamaan.
$\mathrm{u}_{\mathrm{ijt}} \quad$ : error term

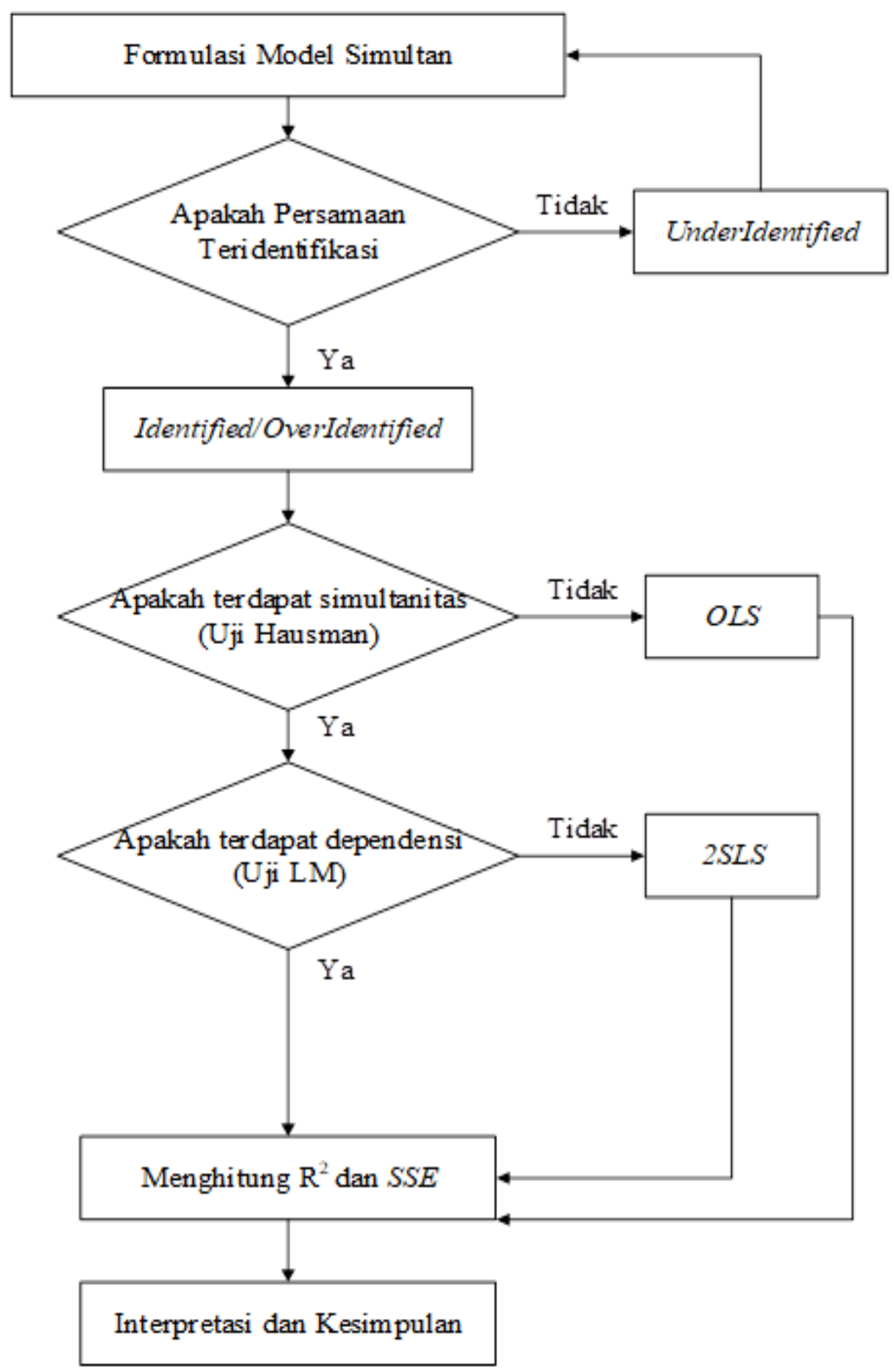

Gambar 3. Diagram Alur Analisis 


\section{HASIL DAN PEMBAHASAN}

\section{Gambaran Umum}

\section{Gambaran Umum Komponen Pertumbuhan Inklusif}

Keadaan perekonomian Sumatera Utara terus mengalami peningkatan. Hal ini tercermin dari indikator pertumbuhan ekonomi yang senantiasa positif, dimana Produk Domestik Regional Bruto (PDRB) atas dasar harga konstan (ADHK) mengalami kenaikan sejak tahun 2013 senilai 398.73 triliun rupiah menjadi 487.53 triliun rupiah di tahun 2017 (Gambar 5). Hal yang perlu diperhatikan bahwa pada tahun 2014, pertumbuhan ekonomi Sumatera Utara 5.23 persen lebih lambat apabila dibandingkan dengan pertumbuhan ekonomi tahun sebelumnya yang mencapai 6.08 persen.

Perlambatan pertumbuhan ekonomi yang terjadi pada tahun 2014 diduga diakibatkan oleh perlambatan pada sektor pertanian. Perekonomian Sumatera Utara masih ditopang oleh sektor Pertanian dengan kontribusi pada tahun 2014 sebesar 23.26 persen. Pertumbuhan sektor pertanian khususnya tanaman pangan dan hortikultura mengalami pertumbuhan negatif masing-masing sebesar -1.59 persen dan -9.13 persen. Perkebunan sebagai penyumbang terbesar pada sektor pertanian Sumatera Utara juga melambat meskipun tidak sampai negatif yaitu dari 6.31 persen pada tahun 2013 menjadi 6.19 persen pada tahun 2014.

Hasil pengamatan Bank Indonesia pada Survei Kegiatan Dunia Usaha (SKDU) menyimpulkan bahwa guncangan perekonomian Indonesia akibat kenaikan suku bunga kredit dan pelemahan nilai tukar rupiah turut memengaruhi perekonomian Sumatera Utara. Guncangan tersebut menyebabkan turunnya permintaan pada sektor hotel dan restoran. Laju pengeluaran rumah tangga akan hotel dan restoran melambat dari 7.46 persen menjadi 6.39 persen pada tahun 2014.

Pertumbuhan ekonomi sejatinya harus inheren dengan penurunan tingkat kemiskinan. Pertumbuhan yang pro-poor merupakan modal utama bagi tercapainya pertumbuhan inklusif (Kakwani dan Pernia 2000).

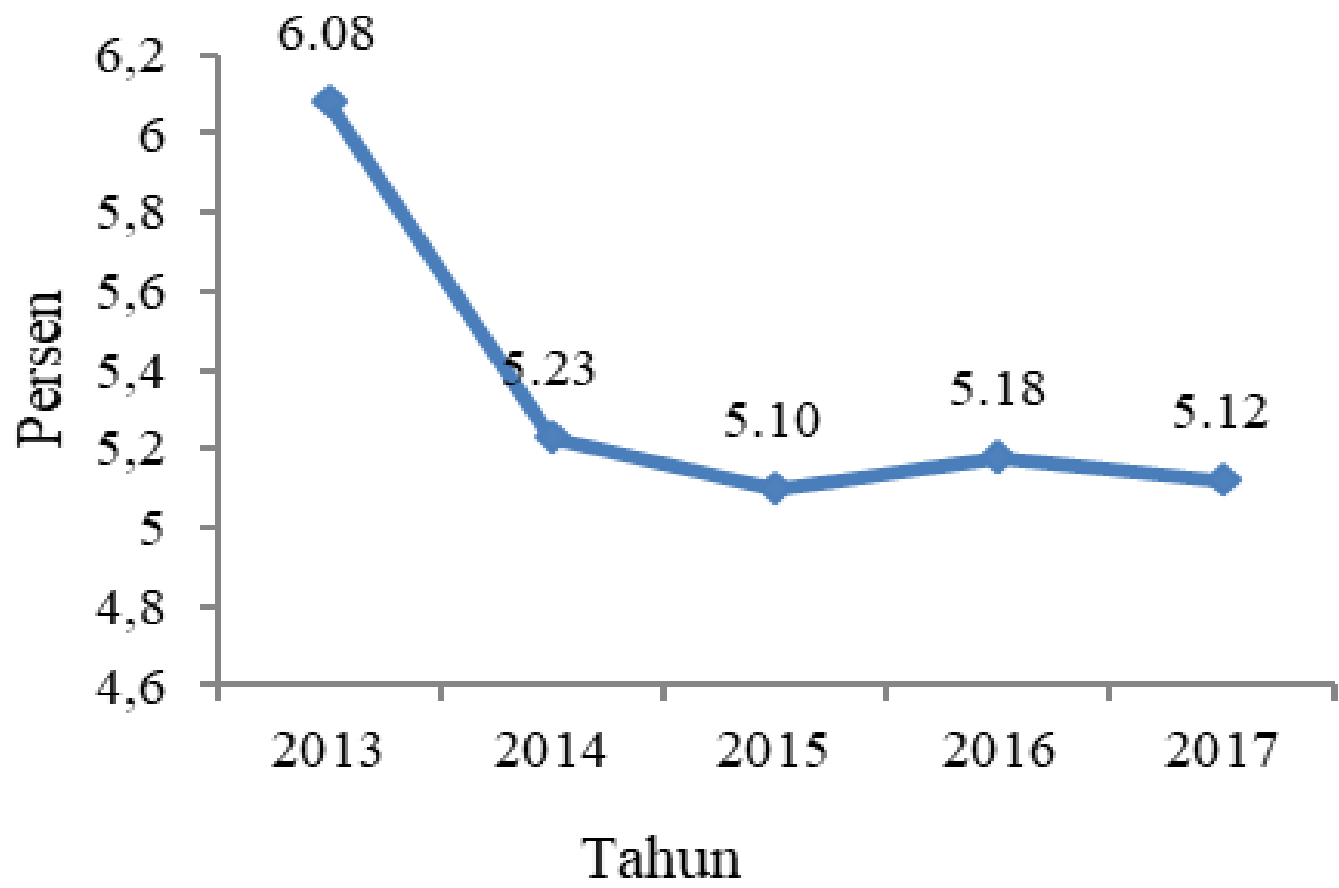

Sumber: Badan Pusat Statistik Tahun 2013-2017

Gambar 4. Pertumbuhan Ekonomi Provinsi Sumatra Utara Tahun 2013-2017 
Berdasarkan data Badan Pusat Statistik (BPS 2017c), jumlah penduduk miskin Sumatera Utara tahun 2013 mencapai 1.36 juta jiwa atau 10.06 persen dari total penduduk. Pada tahun 2017 jumlah penduduk miskin meningkat menjadi 1.45 juta jiwa dan diikuti oleh kenaikan persentase kemiskinan sebesar 10.22 persen. Perlambatan ekonomi selama lima tahun terakhir ternyata sejalan dengan lambatnya proses pengentasan kemiskinan di Sumatera Utara (Gambar 4).

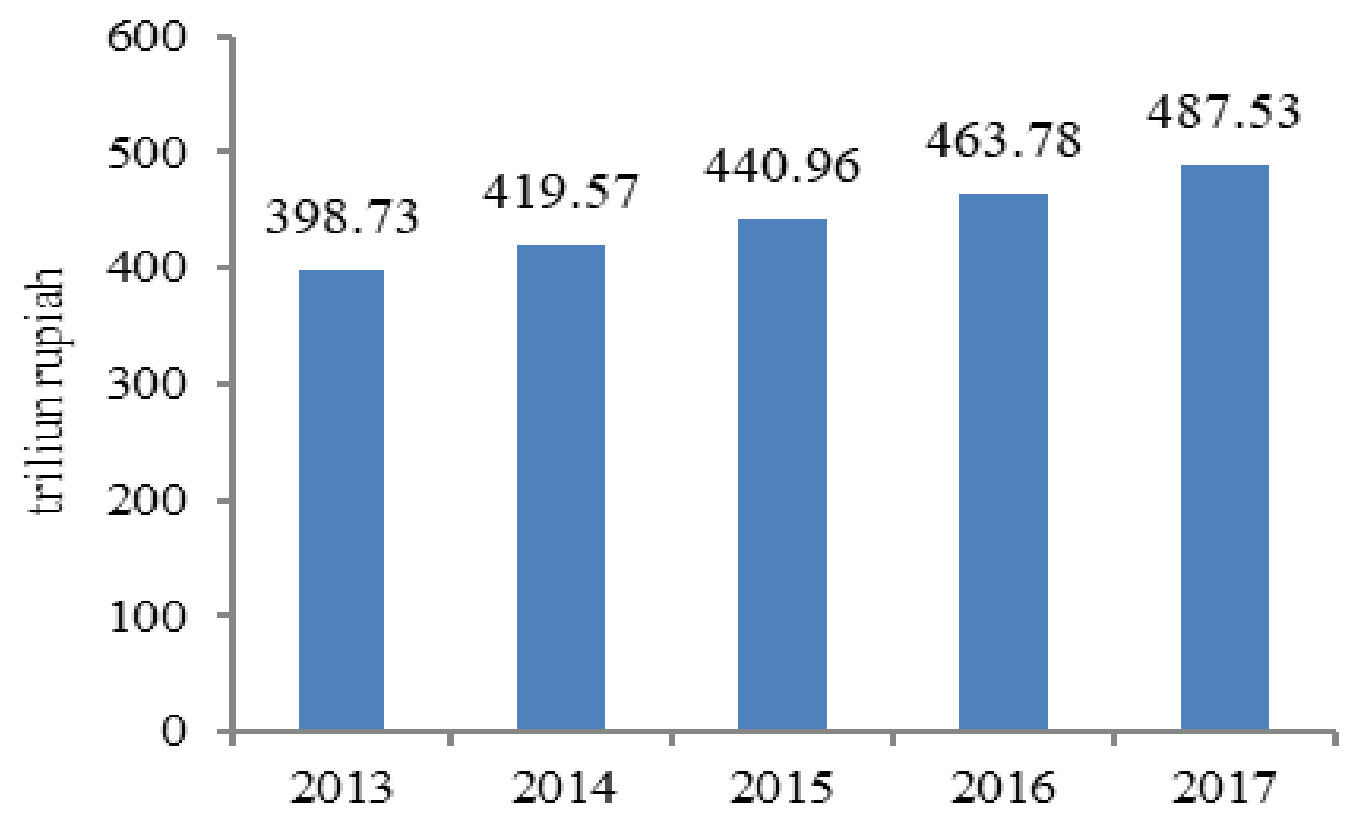

Gambar 5. Perkembangan PDRB ADHK Provinsi Sumatera Utara Tahun 2013-2017.

Sumber : Badan Pusat Statistik Tahun 2013-2017

Tingkat kemiskinan rata-rata kabupaten/kota ternyata berada di atas kemiskinan provinsi. Hal tersebut mengindikasikan terdapat kabupaten/ kota yang menjadi kantong kemiskinan. Berdasarkan data BPS tahun 2017, terdapat 23 kabupaten/kota dengan tingkat kemiskinan di atas 10 persen, sementara itu 3 kabupaten memiliki tingkat kemiskinan di atas 20 persen yaitu Kabupaten Nias Utara, Nias Barat, dan Kota Gunungsitoli dengan persentase kemiskinan masing-masing sebesar 29.06, 27.23, dan 21.66 persen (BPS 2017c).

Isu inklusifitas perekonomian erat kaitannya dengan bagaimana pertumbuhan didistribusikan secara merata kepada penduduk. Distribusi pendapatan penduduk dicerminkan melalui Gini Rasio. Nilai Gini Rasio Provinsi Sumatera Utara selama 5 tahun terakhir mengalami penurunan meskipun sempat mengalami kenaikan pada tahun 2015 dan 2017 (Gambar 5). Hal tersebut mengindikasikan bahwa pendistribusian pertumbuhan ekonomi kepada masyarakat semakin merata atau ketimpangan pendapatan menurun. Jika dibandingkan dengan tren pertumbuhan ekonomi, maka tren sejak tahun 2014 pada pertumbuhan ekonomi dan Gini Rasio memiliki arah yang berlawanan. Laju pertumbuhan ekonomi yang meningkat diikuti oleh penurunan Gini Rasio, artinya secara deskriptif pertumbuhan ekonomi yang tinggi dapat meningkatkan pemerataan pendapatan Sumatera Utara. Ketimpangan Provinsi Sumatera Utara masuk dalam kategori rendah yaitu di bawah 40 persen.

Rata-rata Gini rasio kabupaten/kota berada di bawah Gini Rasio provinsi, artinya Gini Rasio di level kabupaten/kota rendah tetapi ketimpangan pendapatan antar wilayah cukup tinggi dan terdapat wilayah-wilayah padat penduduk yang memiliki ketimpangan tinggi. Menurut data BPS tahun 2016, Kota Medan sebagai ibu kota provinsi memiliki jumlah penduduk terbesar dengan ketimpangan pendapatan yang paling tinggi yaitu sekitar 35 persen (BPS 2017c). 


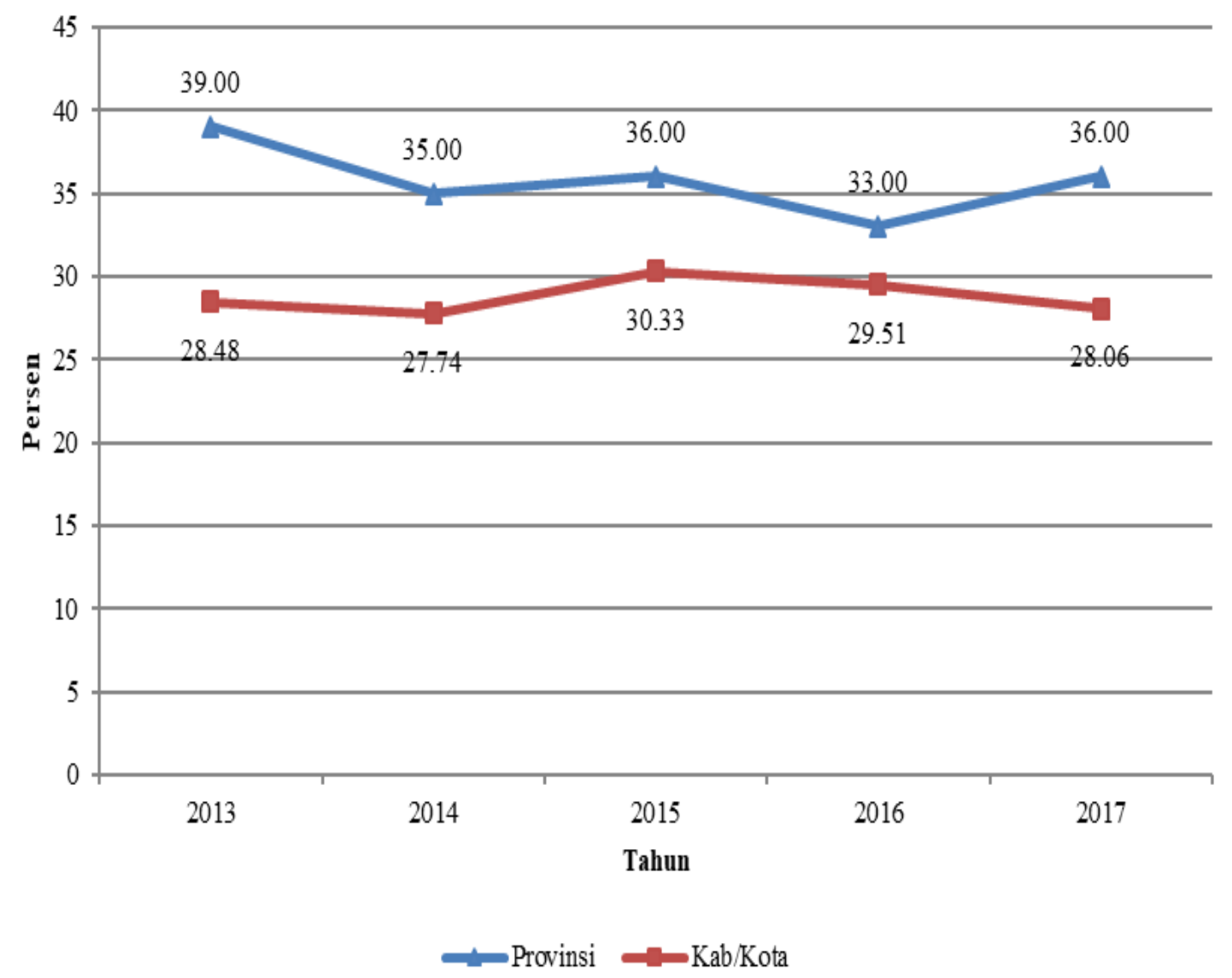

Gambar 6. Perkembangan Gini Rasio Provinsi Sumatera Utara Tahun 2013-2017.

Sumber: Badan Pusat Statistik Tahun 2013-2017

Penciptaan lapangan kerja baru khususnya bagi penduduk miskin atau golongan berpendapatan rendah merupakan langkah pasti dalam menciptakan pertumbuhan inklusif. Dengan bekerja maka seseorang akan mendapatkan penghasilan untuk hidup secara layak dan setara. Penciptaan lapangan kerja baru di Sumatera Utara selama lima tahun terakhir menunjukkan kinerja yang baik. Persentase penduduk bekerja tahun 2017 meningkat signifikan dibandingkan pada tahun 2013. Tren peningkatan persentase penduduk bekerja sempat anjlok pada tahun 2015.

Hal tersebut sejalan dengan semakin lambatnya pertumbuhan ekonomi, selama 5 tahun terakhir, pertumbuhan ekonomi yang terjadi tahun 2015 merupakan yang terendah. Data BPS menunjukkan terjadinya penurunan daya serap tenaga kerja pada sektor pertanian dan industri yaitu dari 42.52 persen menjadi 41.30 persen untuk pertanian dan dari 7.84 persen menjadi 7.55 persen untuk sektor industri. Turunnya penyerapan ini diduga adanya peralihan tenaga kerja ke sektor jasa di mana sektor ini lebih kecil peranannya dibanding sektor pertanian dan industri bagi perekonomian Sumatera Utara.

\section{Estimasi Parameter Persamaan Simultan}

Langkah dalam estimasi parameter diawali dengan uji kebaikan model seperti uji simultanitas, uji endogenitas, dan identifikasi persamaan simultan. Hasil uji simultanitas dan endogenitas menyimpulkan bahwa secara statistik model persamaan simultan layak digunakan selain didukung oleh teori. Identifikasi persamaan simultan dengan aturan order condition dan rank condition pada empat persamaan struktural menghasilkan hasil identifikasi yang over identified, sehingga estimasi OLS tidak dapat dilakukan. Pada kondisi tersebut metode estimasi dengan 2SLS lebih efisien digunakan. Hasil seleksi model terbaik antara model estimasi dengan Seemengly Unrelated Regression (SUR) dan Two Stage Least Square (2SLS) didapatkan bahwa model estimasi dengan 2SLS lebih baik dibandingkan 
SUR. Hal tersebut ditunjukkan dari nilai determinan kovarian sisaan dan simpangan baku sisaan dari metode 2SLS yang lebih kecil daripada metode SUR. Hasil estimasi parameter dapat dilihat pada Tabel 1.

Tabel 1. Hasil Estimasi Parameter

\begin{tabular}{|c|c|c|c|c|c|c|}
\hline \multirow{2}{*}{ Variabel } & \multicolumn{3}{|c|}{$2 S L S$} & \multicolumn{3}{|c|}{ SUR } \\
\hline & Koefisien & Prob. & $R^{2}$ & Koefisien & Prob. & $R^{2}$ \\
\hline \multicolumn{7}{|c|}{ (a) Variabel respon $=\ln P D R B$} \\
\hline Constant & $2.253^{*}$ & 0.000 & 0.9975 & $2.224 *$ & 0.000 & 0.9976 \\
\hline GINI & -0.001 & 0.489 & & -0.000 & 0.947 & \\
\hline InDAK & $0.015^{*}$ & 0.000 & & $0.015^{*}$ & 0.000 & \\
\hline InPMTB & $0.944^{*}$ & 0.000 & & $0.944 *$ & 0.000 & \\
\hline \multicolumn{7}{|c|}{ (b) Variabel respon $=B E K E R J A$} \\
\hline Constant & $114.231^{*}$ & 0.000 & 0.2400 & $114.002 *$ & 0.000 & 0.2315 \\
\hline $\operatorname{InPDRB}$ & $-1.351^{*}$ & 0.000 & & $-1.334 *$ & 0.000 & \\
\hline InJALAN & $0.386^{*}$ & 0.008 & & $0.383^{*}$ & 0.007 & \\
\hline LISTRIK_P & -0.000 & 0.577 & & -0.000 & 0.619 & \\
\hline \multicolumn{7}{|c|}{ (c) Variabel respon $=$ MISKIN } \\
\hline Constant & $55.637^{*}$ & 0.000 & 0.2655 & $58.060 *$ & 0.000 & 0.2805 \\
\hline InPDRB & $-2.700 *$ & 0.000 & & $-2.847^{*}$ & 0.000 & \\
\hline$A I R \_P$ & -0.004 & 0.871 & & -0.004 & 0.859 & \\
\hline \multicolumn{7}{|c|}{ (d) Variabel respon $=$ GINI } \\
\hline Constant & $28.061^{*}$ & 0.000 & 0.1026 & $28.252^{*}$ & 0.000 & 0.1024 \\
\hline InPDRB & $1.031 *$ & 0.037 & & $1.1033^{*}$ & 0.019 & \\
\hline InJALAN & $-0.699 *$ & 0.001 & & $-0.695 *$ & 0.001 & \\
\hline InDBHP & -1.162 & 0.154 & & $-1.296 *$ & 0.089 & \\
\hline
\end{tabular}

Keterangan: * signifikan di dalam model

\section{Inklusifitas Pertumbuhan Ekonomi Sumatera Utara}

Pertumbuhan ekonomi dikatakan inklusif apabila pertumbuhan yang terjadi mampu mengurangi kemiskinan dan ketimpangan serta menyediakan kesempatan kerja yang lebih banyak bagi penduduk. Berdasarkan estimasi model persamaan simultan, diperoleh bahwa pertumbuhan ekonomi di Sumatera Utara sudah mampu mengurangi kemiskinan (pro-poor) (Tabel 1(c)). Namun pertumbuhan ekonomi yang terjadi belum mampu menciptakan kesempatan kerja yang lebih luas (Tabel 1(b)) dan memperburuk ketimpangan (Tabel 1(d)). Hasil tersebut membuktikan bahwa pertumbuhan ekonomi di Sumatera Utara tidak inklusif.

\section{Pertumbuhan ekonomi menurunkan kemiskinan}

Pengentasan kemiskinan merupakan tujuan pokok dari pertumbuhan inklusif. Peningkatan kesempatan bagi orang miskin secara tidak langsung akan menciptakan pemerataan, artinya dengan meningkatnya pendapatan orang miskin akan mempersempit jarak ketimpangan antar golongan pendapatan.

Hasil penelitian menunjukkan bahwa pertumbuhan ekonomi Sumatera Utara sudah memberikan keuntungan bagi orang miskin atau 
dikenal dengan pro-poor growth. Pertumbuhan ekonomi sebesar 1 persen dapat membantu pengentasan kemiskinan sebesar 0.027 persen dengan asumsi ceteris paribus (Tabel 1(c)). Hasil ini sejalan dengan penelitian World Bank dalam Tambunan (2011) yang membuktikan adanya mekanisme pertumbuhan ekonomi dalam mengentaskan kemiskinan, yaitu melalui penciptakan lapangan kerja atau peningkatan pendapatan bagi orang miskin sehingga mereka dapat meningkatkan kualitas hidupnya di atas batas kemiskinan. Dampak pertumbuhan ekonomi terhadap kemiskinan relatif kecil namun signifikan. Minimnya dampak tersebut diduga disebabkan rendahnya produktivitas pekerja miskin dan kebanyakan dari mereka terserap pada lapangan kerja informal dengan pendapatan tidak menentu.

\section{Pertumbuhan ekonomi tidak menciptakan kesempatan kerja yang lebih luas}

Pertumbuhan ekonomi merupakan cermin adanya peningkatan jumlah produksi barang dan jasa yang dihasilkan oleh suatu wilayah. Pada fungsi produksi, salah satu input penting adalah tenaga kerja. Peningkatan produksi dapat berarti juga peningkatan penggunaan tenaga kerja.

Hasil penelitian ternyata membuktikan bahwa pertumbuhan ekonomi yang terjadi di Sumatera Utara belum dapat menciptakan kesempatan kerja yang lebih luas. Pertumbuhan ekonomi sebesar 1 persen mengurangi kesempatan kerja sebesar 0.014 persen (Tabel 1(b)). Artinya, pertumbuhan yang terjadi bukan akibat penambahan tenaga kerja, melainkan disebabkan penambahan faktor produksi lain seperti modal atau teknologi. Penyebab lain yang mungkin terjadi adalah pertumbuhan angkatan kerja yang jauh lebih cepat dibandingkan pertumbuhan lapangan kerja yang tersedia.

Hasil antara pertumbuhan ekonomi dengan kemiskinan dan kesempatan kerja dapat juga terkait dengan kebijakan pengentasan kemiskinan yang dilakukan masih bersifat konsumtif, transfer, atau bantuan langsung yang berdampak jangka pendek.

Pertumbuhan ekonomi berpotensi meningkatkan ketimpangan pendapatan Hipotesis Kuznets menyebutkan bahwa pada awal perekonomian suatu wilayah, pertumbuhan ekonomi yang terjadi akan meningkatkan ketimpangan pendapatan antar penduduk. Hal tersebut disebabkan adanya proses pemusatan ekonomi pada sektor industri sehingga mengorbankan sektor-sektor lain di bawahnya. Pada tahap berikutnya pertumbuhan ekonomi akan menciptakan pemerataan pendapatan penduduk yang disebabkan oleh trickle down effect sektor industri dan perkembangan sektor jasa.

Hasil penelitian menunjukkan bahwa pertumbuhan ekonomi di Sumatera Utara justru berpotensi meningkatkan ketimpangan. Pertumbuhan ekonomi sebesar 1 persen akan menyebabkan kenaikan ketimpangan pendapatan sebesar 0.01 persen dengan asumsi ceteris paribus. Temuan ini sejalan dengan adanya fakta bahwa perekonomian Sumatera Utara masih ditopang oleh sektor pertanian, dimana berdasarkan hipotesis Kuznets, maka perekonomian Sumatera Utara masih dalam kondisi awal dan masih terus berkembang.

Penelitian World Bank (2016) juga menemukan bahwa pertumbuhan ekonomi Indonesia pada periode 2010-2016 meningkatkan ketimpangan pendapatan penduduk. Pertumbuhan ekonomi hanya dinikmati oleh segelintir orang yaitu 20 persen golongan pendapatan tertinggi. Ketidakmerataan distribusi pertumbuhan ekonomi menyebabkan golongan pendapatan terendah semakin tertinggal dalam pembangunan dan memperlembar kesenjangan.

\section{Dampak Infrastruktur pada Pertumbuhan Inklusif}

\section{Investasi infrastruktur sebagai mesin pertumbuhan ekonomi}

Pembangunan infrastruktur merupakan syarat perlu bagi keberlangsungan perrtumbuhan ekonomi Indonesia (Maryaningsih et al. 2014). Jaminan keberlangsungan pembangunan infrastruktur adalah adanya ketersediaan modal pembangunan yang cukup. Modal pembangunan infrastruktur dapat disediakan oleh pemerintah maupun swasta. Investasi oleh pemerintah pusat kepada daerah dilakukan dengan alokasi dana khusus (DAK), sedangkan investasi yang dilakukan oleh swasta tercermin oleh pembentukan modal tetap bruto (PMTB). 
Hasil penelitian menunjukkan adanya dampak positif yang diberikan oleh kegiatan investasi melalui DAK dan PMTB terhadap pertumbuhan ekonomi di Sumatera Utara (Tabel 1(a)). Peningkatan alokasi DAK sebesar 1 persen dapat memacu pertumbuhan ekonomi sebesar 0.015 persen (ceteris paribus), sedangkan peningkatan PMTB sebesar 1 persen akan memacu pertumbuhan ekonomi sebesar 0.944 persen. Hasil keduanya menyiratkan bahwa peran swasta berperan lebih tinggi dalam pembangunan infrastruktur dan pertumbuhan ekonomi regional. Peran pemerintah seharusnya terbatas sebagai stimulus dan pemberi kebijakan terkait investasi karena tujuan utama pemerintah adalah kemakmuran dan pemerataan. Sedangkan swasta memiliki tujuan utama yaitu peningkatan laba dan efisiensi produksi yang nantinya berdampak pada pertumbuhan ekonomi yang tinggi.

\section{Pembangunan jalan untuk akses kesempatan kerja dan distribusi pendapatan}

Peran jalan sebagai penghubung antar unitunit ekonomi sangat penting. Ketersediaan jalan penghubung akan mempermudah akses sektor ke sumber daya atau sebaliknya. Jalan juga berfungsi sebagai saluran distribusi perekonomian ke wilayah-wilayah lain di sekitar pusat pertumbuhan sehingga pemerataan terjadi. Kegiatan ekonomi akan tumbuh di sepanjang jalan sehingga menciptakan kesempatan ekonomi bagi siapapun (Prasetyo dan Firdaus 2009).

Hasil penelitian membuktikan bahwa semakin panjang jalan yang dibangun di Sumatera Utara, maka akan semakin besar peluang penduduk untuk bekerja. Peningkatan panjang jalan sebesar 10 persen akan menciptakan peluang bekerja sebesar 0.038 persen (ceteris paribus). Penambahan panjang jalan juga dapat menurunkan ketimpangan pendapatan di Sumatera Utara. Peningkatan panjang jalan sebesar 10 persen dapat menurunkan ketimpangan pendapatan sebesar 0.070 persen. Hasil tersebut menguatkan pentingnya pembangunan jalan di Sumatera Utara bagi tercapainya pertumbuhan inklusif.

\section{Gambaran Umum Infrastruktur di Provinsi Sumatera Utara}

Pembangunan infrastruktur yang telah dilakukan selama 5 tahun terakhir telah mengalami pertumbuhan yang signifikan, dimana penambahan panjang jalan dan meningkatnya persentase rumah tangga yang memiliki akses air bersih dan akses listrik di kabupaten/kota di Provinsi Sumatera Utara. Peningkatan panjang jalan terus mengalami peningkatan yaitu pada tahun 2013 panjang jalan maksimum di kabupaten/kota sebesar $3242.88 \mathrm{~km}$ menjadi $3890.45 \mathrm{~km}$ pada tahun 2017.

Pembangunan infrastruktur jaringan jalan, fasilitas air ledeng serta jaringan listrik merupakan sebagai pembentuk struktur ruang nasional memiliki keterkaitan yang sangat kuat dengan pertumbuhan ekonomi suatu wilayah maupun sosial budaya kehidupan masyarakat. Dalam konteks ekonomi, jalan sebagai modal sosial masyarakat merupakan tempat bertumpu perkembangan ekonomi, sehingga pertumbuhan ekonomi yang tinggi sulit dicapai tanpa ketersediaan jalan yang memadai Tambunan (2005) menegaskan bahwa manfaat ekonomi infrastruktur jalan sangat tinggi apabila infrastruktur tersebut dibangun tepat untuk melayani kebutuhan masyarakat dan dunia usaha yang berkembang.

Statistik deskriptif persentase rumah tangga yang memiliki akses air ledeng di Provinsi Sumatera Utara menunjukan bahwa terjadi peningkatan tahun 2013 yaitu dari 65.94 persen menjadi 77.80 persen pada tahun 2017. Nilai minimun rumah tangga yang belum memiliki akses air ledeng sebesar 0 persen disebabkan adanya beberapa kabupaten/kota di Provinsi Sumatera Utara yang belum memiliki Perusahaan Air minum (PDAM).

Statistik deskriptif persentase rumah tangga yang memiliki akses listrik di Provinsi Sumatera Utara menunjukan adanya kabupaten/kota yang masih rendah persentase rumah tangga yang memiliki akses listrik yaitu 42.96 persen pada tahun 2013 namun mengalami peningkatan pada tahun 2017 sebesar 55.00 persen. Nilai maksimum sebesar 100 persen menunjukan adanya kabupaten/kota yang masyarakatnya sudah seluruhnya memiliki akses listrik. 


\section{SIMPULAN DAN SARAN}

\section{Simpulan}

Berdasarkan hasil pembahasan baik melalui analisis deskriptif maupun analisis kuantitatif menggunakan model simultan dengan metode two-stage least square (2SLS) maka dapat ditarik beberapa kesimpulan sebagai berikut:

1. Sumatera Utara berhasil mempertahankan pertumbuhan ekonomi yang positif meskipun pada laju pertumbuhan terus melambat. Kemiskinan, ketimpangan dan pengangguran selama 5 tahun terakhir ditekan.

2. Estimasi model persamaan simultan memperlihatkan bahwa pertumbuhan ekonomi di Sumatera Utara sudah mampu mengurangi kemiskinan (pro-poor). Namun pertumbuhan ekonomi yang terjadi belum mampu menciptakan kesempatan kerja yang lebih luas dan memperburuk ketimpangan. Hasil tersebut menyimpulkan bahwa pertumbuhan ekonomi di Sumatera Utara tidak inklusif.

3. Pembangunan infrastruktur di Sumatera Utara mendorong pertumbuhan ekonomi, dimana infrastruktur jalan meningkatkan akses kesempatan kerja serta distribusi pendapatan yang lebih merata.

\section{Saran}

Berdasarkan hasil penelitian ini maka dalam rangka mewujudkan pertumbuhan ekonomi yang inklusif, pemerintah dalam mengambil kebijakan sebagai berikut:

1. Pertumbuhan ekonomi Sumatera Utara harus tumbuh lebih cepat untuk dapat mengentaskan kemiskinan dengan menciptakan lapangan kerja melalui memudahkan investor untuk membuka usaha. Ketersediaan lapangan kerja dengan pendapatan yang layak perlu ditingkatkan sehingga orang miskin tidak hanya mendapatkan pekerjaan tetapi juga memiliki kesempatan lebih untuk meningkatkan taraf hidup.

2. Pemerintah sebaiknya mengalihkan bantuan yang bersifat konsumtif atau bantuan langsung tunai kepada bantuan yang bersifat produktif melalui pelatihan kerja bagi orang miskin, pembinan dan bantuan modal bagi UMKM.
3. Pemerintah harus membuka lebar PMU terhadap investasi swasta khususnya investasi dalam negeri di bidang infrastruktur. Peningkatan panjang jalan raya perlu terus dilakukan untuk meningkatkan aksesbilitas penduduk terhadap kesempatan kerja.

\section{DAFTAR PUSTAKA}

Ali I, Son HW. 2007. Measuring Inclusive Growth. Asian Development Review. 24(1):11-31.

Ali I, J Zhuang. 2007. Inklusif Growth toward a Prosperous Asia: Policy Im-plications. ERD Working Paper Series, No. 97. Manila: ADB

Baltagi BH. 2005. Econometric Analysis of Panel Data Third Edition. John Wiley \& Sons: England.

World Bank. 1994. World Development Report: infrastructure for development. New York (US): Oxford University Press, Inc.

World Bank. 2016. Indonesia's Rising Divide: Why Inequality Is Rising, Why It Matters, and What Can Be Done. Jakarta: World Bank.

[BAPPENAS] Badan Perencanaan Pembangunan Nasional. 2014. Rencana Pembangunan Jangka Menengah Nasional 2015-2019. Buku I Agenda Pembangunan Nasional. Jakarta (ID): BAPPENAS.

[BPS] Badan Pusat Statistik. 2017a. Analisis Isu Terkini. Badan Pusat Statistik: 31-62. Jakarta(ID): BPS RI.

[BPS] Badan Pusat Statistik. 2017b. PDRB Kabupaten-Kota se-Sumatera Utara Menurut Pengeluaran 2013-2017. Medan (ID): BPS Sumatera Utara.

[BPS] Badan Pusat Statistik. 2017c. Indikator Kesejahteraan Rakyat Provinsi Sumatera Utara 2017. Medan (ID): BPS Sumatera Utara.

[BPS] Badan Pusat Statistik. 2017d. Peta Tematik Indikator Sosial Ekonomi Provinsi Sumatera Utara 2017. Medan (ID): BPS Sumatera Utara.

Brenneman A, Michel K. 2002. Infrastructure \& Poverty Linkages: A Literature Review. Washington DC: The World Bank. 
Calderon C, Lui S. 2005. The Effects of Infrastructure Development on Growth and Income Distribution. World Bank Policy Research Working Paper Series No. 3643. Washington DC: World Bank.

Gibson J, Susan O. 2009. The Effect of Infrastructure Access and Quality on Non-Farm Enterprises in Rural Indonesia. World Development. 38(5): 717-726.

Ianchovichina E, Gable SL. 2009. Inclusive Growth Analytics Framework and Application. Policy Research Working Paper 4851: The World Bank Economic Policy and Debt DepartmentEconomic Policy Division.

Klasen S. 2010. Measuring and Monitoring Inclusive Growth: Multiple Definitions, Open Questions, and Some Constructive Proposals. ADB Sustainable Development Working Paper Series.
Kakwani N, Pernia EM. 2000. What is Pro-Poor Growth? Asian Development Review.18(1): 1-16.

Mankiw NG. 2016. Macroeconomics, Ninth edition. Harvard University. New York (US): Worth Publisher.

Maryaningsih $\mathrm{N}$, et al. 2014. Pengaruh Infrastruktur terhadap pertumbuhan Ekonomi Indonesia. Buletin Ekonomi Moneter dan Perbankan 17(1): 61-98.

Prasetyo, Firdaus. 2009. Pengaruh Infrastruktur pada Pertumbuhan Ekonomi Wilayah di Indonesia. Jurnal Ekonomi dan Kebijakan Pembangunan, 2(2), 222-236.

Todaro Michael P, Smith Stephen C. 2015. Economic Development. 12th Edition. Library of Congress Cataloging-inPublication Data. New York University and The George Washington University.

Tambunan T H. 2011. Perekonomian Indonesia. Jakarta: Ghalia Indonesia. 